\title{
"Ein Lichtpunkt von demanthaftem Feuer": Karl Wolfskehl's Visit to Dunedin
}

Letters written by Karl Wolfskehl after his visit to Dunedin in January 1941 show that the weeks spent there proved revitalising in a way which certainly exceeded his initial expectations and in recollection came to represent an emotional high point amidst the difficulties of his New Zealand exile.' In Dunedin Wolfskehl's outward journey reached its geographical extremity and yet there of all places and just a few weeks later in Christchurch, he was able to experience briefly but intensely a feeling of reunion, even of being at home in New Zealand, the positive emotional after-image of which persisted for some months and may well have helped him through the severe cardiac illness which befell him later that same year. Wolfskehl wrote afterwards to Laudenheimer: "Das war eine so starke Auffrischung, ja gradezu Verjüngung für mich, wie ich es nicht mehr für möglich gehalten hätte." 2 After the illness, depression and loneliness which had severely afflicted Wolfskehl in Auckland in 1940, the weeks spent with Cäsar and Hanna Steinhof in Dunedin and his meetings with fellow German- and Austrian-Jewish exiles there lifted his spirits considerably:

Wie in Christchurch war ich auch in Dunedin bei Freunden - ohne solche Bequemlichkeit wäre mir ja die ganze Reise auch schon aus materiellen Gründen nicht möglich gewesen - und durch deren $\mathrm{Be}$ ziehungen wie auch allerlei glückliche Zufälle hatte ich die gün stigste, natürlich auch wohlbenutzte Gelegenheit, mein etwas ein gefrorenes Dasein wieder in Schwung und zum Tönen zu brin gen. ${ }^{3}$

1 References to Wolfskehl's published correspondence are to the following volumes: Margot Ruben, ed., Karl Wolfskehl: Zehn Jahre Exil - Briefe aus Neuseeland 1938-1948, Heidelberg/Darmstadt 1959, cited hereafter as BaN I, and Cornelia Blasberg, ed., Karl Wolfskehls Briefwechsel aus Neuseeland 1938-1948, 2nd ed., 2 vols., Darmstadt 1988, cited hereafter as BaN II. I am also grateful to Friedrich Voit for allowing me access to extracts from Wolfskehl's unpublished correspondence which he transcribed at the Deutsches Literaturarchiv, Marbach, while gathering material for his biographical study of Wolfskehl. References to extracts from unpublished letters are identified by DLA.

2 KW to Rudolf Laudenheimer, 26. 6. 1941, BaN II, p. 456.

$3 \mathrm{KW}$ to Ernst Gundolf 15. 4. 1941, BaN II, p. 437. 
In correspondence with Otti Binswanger Wolfskehl emphasised that what he experienced in Dunedin and Christchurch awakened in him for the first time in New Zealand positive associations with the lost 'Heimat':

Wie in ein Stück Heimat blickt' ich zurück, denk ich nun dauernd hinüber! Könnt ich mich nur ausströmen, wär nur nicht die Drohung des Illegible immer über mir, jeden Federzug hemmend oder regulierend! Sie müssen unendlich viel Ungesprochenes, Ungeschriebenes vernehmen mit dem inneren $\mathrm{Ohr}$ [...]. Was hatten wir alles zu berichten und wie war auch das Schweigen kein Verschweigen! Jeder fühlte den Andren, sein Ringen wie seine Ruh [...]. Ich glaub ich bin jetzt erst heimisch in New Zealand.4

Wolfskehl left Auckland alone on 7 January 1941 and travelled by train to Dunedin via Christchurch where Margot Ruben was to join him on his return. Impressions of the journey, set down in a style which Wolfskehl compares to a half-finished water-colour sketch, appear in a letter to Ernst Gundolf written some two months after his return to Auckland. He notes that his stars were favourable. The notoriously rough passage across Cook Strait and the onward journey by sea to Lyttleton must have been smooth for he makes no mention of them. His depiction of Dunedin's cultural and physical landscape is initially emotionally upbeat and underscores the strong impression which the more striking features of the city and its southern location made on him:

Von da [Christchurch] fährt man noch seine guten sieben Stunden durch oft recht Gundolfische Dünen- und Hügelgegend nach Dune din, einer richtigen Universitätsstadt. Akademische Luft, wissen schaftliche Interessen und eine Anzahl ausgezeichnete Köpfe. [...] Die verschiedenartigsten Menschen, Schicksale und Umstände! Un ter anderem fand ich im dortigen Professor für Englisch einen so außerordentlichen Kenner Swinburnes, daß ich dieser Begegnung geradezu neue Ausblicke und Einsichten verdanke. [...]

Dunedin liegt auch landschaftlich ganz besonders schön in einer Hügelgegend, deren Wellen fast schon am Strand des hier unendlich blauen, schon wie von der Antarktis angeglänzten Ozeans begin nen, mit Gärten und stehengebliebenen, freilich auch schon mit Eichen und Buchen durchsetzten Waldstücken gemischt, die Häuser,

$4 \mathrm{KW}$ to Ottilie Binswanger, 18. 3. [41], DLA. 
hier oft mehrstöckig, über die Kuppen gestreut oder in Mulden ein geschmiegt - das ganze erinnert genau an Bilder aus mittlerer manchmal gar aus der Südschweiz, spricht also heimatlich an. ${ }^{5}$

Continuing the letter a few days later with a self-critical gesture corrective of the exile's tendency to overemphasise the seemingly familiar, the physical correspondences with the Swiss landscape are sombrely relativised:

Ein paar Tage vergingen seit Obigem, und beim Durchlesen find ich's doch gar zu idyllisch, selbst für einen Fern-Exulanten, also im puren Dasein sich zu vergnügen, zumal heute, wo das Wort Ferne jeden Sinn und Inhalt verlor. 6

Despite such qualifications, the evidence of Wolfskehl's correspondence suggests that the impression of a series of positive and uplifting encounters in Dunedin augmented by the benefits of travel and a change of air should remain the dominant one:

Wie sieht sich die Welt und Wesen bis in jede Einzelheit freundlich an wenn wir, unbeschwert und aufnahmewillig, und der Monotonie des Alltags enthoben, uns auf Reisen befinden! Alles ordnet sich wie von selber, alles nimmt man leicht ... . ${ }^{7}$

Why did the Dunedin experience ("und vor allem das wirklich überaus herrliche Dunedin"8) remain for Wolfskehl even half a year later "ein Lichtpunkt von demanthaftem Feuer"9? Was the impression of "eine so fabelhaft kulturelle, richtig akademische Atmosphäre"10 any more than an ageing and almost blind traveller's illusion? Who were the fellow-exiles whose company Wolfskehl so enjoyed in Dunedin? What was the nature of the Dunedin exile community in which they lived? How were the exiles received by the resident Jewish community? How did these two groups differ, if at all, from those which Wolfskehl had encountered in Auckland? Answers to some aspects of these questions can be found in Wolfskehl's correspondence but the letters contain insufficient evidence to reconstruct the visit in more than broad outline: its social and

$5 \mathrm{KW}$ to Ernst Gundolf 15. 4. 1941, BaN II, p. 436-437.

6 Ibid., p. 437.

$7 \mathrm{KW}$ to Dr. F. (Felix Grayeff), 25. 3. 1941, BaN I, p. 86.

$8 \mathrm{KW}$ to Ernst Gundolf 15. 4. 1941, BaN II, p. 436.

$9 \mathrm{KW}$ to Rudolf Laudenheimer, 26. 6. 1941, BaN II, p. 457.

$10 \mathrm{KW}$ to Rudolf Laudenheimer, 26. 6. 1941, BaN II, p. 457. 
cultural context and the precise situation in Dunedin of those exiles with whom he came in contact remain indistinct. The relevant period in the history of Dunedin's Jewish community and in particular the history of the Jewish refugees who gathered there from the late 1930 s, both essential to a fuller understanding of Wolfskehl's visit, have not until now been more than peripherally investigated.11

It was Wolfskehl's friendship with Cäsar and Hanna Steinhof which literally drove him to undertake his South Island journey. He and Margot Ruben had met Cäsar and Hanna Steinhof in Auckland in 1939 and in that first year of their friendship he celebrated the Jewish New Year with them. Wolfskehl's friendship with the Steinhofs was, like his friendship with the Blumenfelds, a vital part of what made his New Zealand exile bearable from the point of view of his Jewish self-identity. Cäsar and Hanna Steinhof had emigrated from Hamburg to Auckland in 1938. In marked contrast to the vast majority of resident and refugee Jews in New Zealand whose ancestors, where not of Sephardic origin, had passed through the gateway of the Haskalah and entered into various degrees of assimilation, the Steinhofs were Orthodox.12 Hanna Urmann's [Stein-

11 A direct result of preliminary research for this paper was the discovery that an uncatalogued collection of documents belonging to the Dunedin Jewish Congregation had been deposited recently in Dunedin's Hocken Library. The collection includes correspondence and records of the Dunedin Branch of the New Zealand Jewish Welfare Society (hereafter DJWS) relating to the situation of Jewish refugees in Dunedin generally and in particular to the refugee doctors and dentists undergoing compulsory retraining at the Otago Medical School. Working out from this body of material and utilising information gained from interviews with surviving Dunedin refugees and members of the Dunedin congregation Christine Baumberg has produced a comprehensive historical study, Ripples from Europe. The Dunedin Jewish Community in the 1930s and 1940s, BA Hons. dissertation in History and German, University of Otago, 1998. I am grateful to Christine Baumberg for the ground-breaking research she has carried out and for her permission to cite here evidence from unpublished transcripts of material from the Collection of Mr E. Friedlander.

12 Cäsar Steinhof, born in Segeberg in 1909, was a descendant of the Sofer (Schreiber) rabbinical family. He could trace his family tree back to Moses Sofer of Pressburg in Hungary, the founder of a large and very famous yeshivah. Moses Sofer became the leader of European rabbinical resistance to the Reform movement. Abraham Samuel Benjamin Wolff (1815-1871), the oldest son of Moses Sofer was "one of the active organisers of Hungarian Jewry for the Jewish Congress which took place in 1869. [...] not at first an extremist, he later joined their ranks and finally gave the religious approval of the Sofer dynasty to the schism in Hungarian Jewry." Encylopaedia Judaica, Vol. 15, Jersualem, 1971: 75-76.

Hanna Steinhof [Stern] was also from a distinguished rabbinical line. On her 
hof's] account of the relationship of her husband and herself with Wolfskehl conveys the emotional and spiritual intensity of their encounter with him against the background of their own struggles to survive in New Zealand: "It all started in Auckland: Margot Ruben was told of a Jewish Reverend, and took my. husband to her flat and [to] Wolfskehl. That was in the first year, and then Karl and my husband, were nearly every night till late together. They had so much in common! In that time I loved Karl and felt compassion for him."13

Of the Jewish friends he made in New Zealand, it was perhaps to the Steinhofs, and to Cäsar Steinhof in particular, that Wolfskehl was able to give utterance to his darkest fears regarding the fate of the Jews, to express most openly his deepest feelings about his own Jewishness and his need to enter at a time of great personal and historical suffering more deeply into questions of faith:

[...] noch nie gab es größere Gefahr für den Weiterbestand jüdischer Wirklichkeit. Das in ewiger Wanderung Welt und Herzen durchziehende Stiftszelt, ob es noch eine Statt findet, ob das größte Vermächtnis weiter getragen wird von Geschlecht zu Geschlecht, ob dieser Planet weiter Schauplatz bleiben wird, Betort, ob Ewigkeit weiterhin sich dartun will als unbrechbare Kette, leitend von Geschlecht zu Geschlecht innerhalb des Erdraums, das und noch man ches andre Fragen quillt jetzt auf, umsteht uns, droht oder verlockt.

[...] Sie, Cäsar Steinhof, sind der erste Jude, mit dem ich mich verstehe als mit einem Juden, ohne irgend andre Zutat, schrankenlos und ungehemmt. Mit M. B. ${ }^{14}$ zum Beispiel war dies nie der Fall, immer blieben wesentliche Dinge unangerührt [...]. Wie anders ist dies mit Ihnen bei so unglaublicher Verschiedenheit in den persön lichen Voraussetzungen, Lebensgängen, Altersstufen. ${ }^{15}$

mother's side she was a descendant of the Carlebach family. Her maternal grandfather was Joseph Carlebach (1882-1942), a rabbi in Lübeck, Altona and Hamburg, who was also for some time Headmaster of the Talmud Torah high school in Hamburg. He perished in a concentration camp near Riga in 1942. Joseph Carlebach was the son of Solomon Carlebach (1845-1919), a Lübeck rabbi and probably the prototype for the rabbi in Thomas Mann's Dr Faustus. Hanna Steinhof's mother was Joseph Carlebach's daughter, Sarah (b. 1880) who had married the Berlin rabbi and historian Moritz Stern. Encylopaedia Judaica, Vol. 5, Jersualem, 1971: 182-183.

13 Hanna Urmann [Steinhof], Melbourne, to F. Voit, 10. 3. 1997.

14 Maja Blumenfeld.

$15 \mathrm{KW}$ to Cäsar and Hanna Steinhof, [August 1939], BaN II, pp. 339 and 341. A passage from Wolfskehl's last letter to Hanna Steinhof reinforces this impres- 
The Steinhofs's decision early in February 1940 to move to Dunedin had signified for Wolfskehl another painful separation, one which must have cut him to the quick. Hanna Steinhof registered the measure of his distress: "The first year was over, Karl cried, do not leave me. [...] Karl was devastated, so I, being high pregnant with the 3. child, promised Karl Wolfskehl, to invite him as soon as possible to Dunedin."16 In the month's before he travelled to Dunedin the Steinhofs were made to feel the strength of Wolfskehl's passion for their company:

Letters after letters, "I need you please come soon! Urgent!" When the little baby-boy was 2 months old, we invited Karl.

Wolfskehl seems to have planned to visit the Steinhofs in Dunedin as early as February 1940, even before they had actually left Auckland 17 The strength of his attachment to them appeared to flow essentially from the current of his spiritual longing:

Wie gern wäre ich einer unter denen, denen Sie vor-beten, vorsingen, vor-verordnen, vor-verheißen! Es wird nicht an dem sein, aber daß 5701 ein Wiedersehen bringe, gehört zu den besten Wünschen, die ich für mich noch auszudenken vermag!

Die ewige Gegenwart Judentum halte uns weiter verfangen. Dies inbrünstige Gebet für jeden und alle umschließt, enthält, was sonst noch auszusprechen wäre, lieber Freund! 18

Whether the Steinhofs privately regarded Wolfskehl as being to some extent "am ha'aretz" (one not knowledgable of or not careful in the proper observance of Jewish law) is not recorded. His almost total lack of Hebrew was almost certainly a barrier but one which was offset by his thirst for a deeper knowledge of Judaism. Despite his generosity of spirit, however, it is not difficult to imagine that Wolfskehl's bohemian liberality, appetite for good food and wine,

sion: "Bitte nimm's so wörtlich als möglich: Ihr seid die einzigen Menschen hier in N.Z., mit denen mich alles verbindet, was Menschen zusammenhaftet und hält, Herz und Geist, Wesen und Gefühl, eine bei dem fast märchenhaften Unterschied der Jahre fast unglaubliche Verschwisterung von Sinn und Sein." KW to Hanna Steinhof, BaN II, p. 345.

16 Hanna Urmann to F. Voit.

17 Friedrich Voit, notes on DLA materials: "Bereits im Februar scheint KW eine

Reise nach Dunedin (zu Steinhofs) [...] und nach Christchurch zu Binswangers

[...] geplant zu haben, die er aus gesundheitlichen Gründen absagt."

$18 \mathrm{KW}$ to Cäsar and Hanna Steinhof, 25 September 1940, BaN II, p. 343. 
enormous creativity and passionate need for conviviality and fellowship placed huge and ultimately insupportable demands on the attention and energies of the much younger Steinhofs whose daily routines were much circumscribed by their Orthodox observance of the laws of the faith at home and in the synagogue, and by their responsibilities as parents:

He stayed for six weeks with us, we gave him the best we could, but in the end, it (=he) overpowered us, swallowed us, we just could not any more, and with a young baby and all the other duties we could not give him ourselves. 19

In this the Steinhofs were not alone. The energy and intensity with which Wolfskehl manifested his intellectual and spiritual vision was not infrequently experienced as engulfing by others. Sargeson's unfeeling break with Wolfskehl in 1943 is certainly the best known example of this in the New Zealand context. ${ }^{20}$ In the case of the Steinhofs there were almost certainly also some aspects of Wolfskehl's earlier experience as a Jewish initiate of the George-Kreis, a cultic and prophetic community far removed from the beliefs and values of Orthodox Judaism, which he did not reveal to them, or if he did, were part of what they perceived as overpowering in him and resisted.

What had induced the Steinhofs themselves to leave Auckland for the much smaller city of Dunedin and in what circumstances and social setting did Wolfskehl now find them there? In September 1939 the Dunedin Jewish Congregation Committee 21 had become aware that Mr Ernst Hirsch, a German-Jewish refugee (the father of New Zealand's first Race Relations Conciliator, Mr Wally Hirsch) who had found employment in a textile factory at Milton some 40 kilometres south of Dunedin, was prevented by the lack of a suitable train connection from being able to reach the Dunedin Synagogue in Moray Place in time to conduct the Sabbath Service. In January 1940, the Committee considered a suggestion from the Reverend Alexander Astor, Rabbi to the Auckland Jewish Community, that a certain Mr Cäsar Steinhof, referred to as a fully certified teacher who had arrived with his family from Germany six months earlier, should be interviewed for the position of Reader and

19 Hanna Urmann to F. Voit.

20 See Michael King, Frank Sargeson: A Life, Auckland 1995, p. 227.

21 Baumberg, notes taken from Minute Book of Congregation Committee, E. Friedlander Collection. 
Sabbath School teacher. The Committee was aware that Steinhof had completed a period of teacher training in Auckland and had applied for a position at King's High School in Dunedin.22 Steinhof's application proved unsuccessful but in February 1940 he met with three Dunedin Congregation Committee members in Wellington who were sufficiently impressed by his character and qualifications to invite him to Dunedin to read a Sabbath Service and meet the children who attended the Sabbath School. On 26 February 1940 the Committee resolved that Steinhof be engaged as Reader and Sabbath School teacher on a six-month trial basis at a salary of $£ 4.00$ per week and with a grant of $£ 50.00$ to assist with the expense of the removal of family and their personal effects from Auckland to Dunedin. As Steinhof's widow, Hanna Urmann, recalled the situation in 1997:

My husband passed his exam very well, a hard exam, before 3 professors.

But what now?

Like a miracle! The same month a letter arrived from Dunedin: We want you as our minister! Synagogue Service. Cheder for the 45 children who arrived with their parents. German doctors who had to study for 3 years, ministerial duties etc, $£ 5$ weekly and a small cottage.

It was at this "small cottage", a modest wooden bungalow still standing at 27 Wallace Street, Maori Hill, just above the city's extensive green belt, that Wolfskehl stayed with the Steinhofs and their three children. In addition to their official functions, the Steinhofs' presence in Dunedin provided a focal point for some of the social activities of the Jewish community. ${ }^{23}$

In Dunedin as in Auckland Wolfskehl must have formed impressions of the relationship of his hosts and other Jewish refugees he met there to the wider Jewish and non-Jewish community, but

22 At King's High School the young James K. Baxter was in 1940-41 already suffering the consequences of his own difference and his family's conscientious objection to military service, experiences which he later compared to those "of a Jewish boy growing up in an anti-Semitic neighbourhood". What the remarkably perceptive young poet would have made of the presence of Cäsar Steinhof at the school or of a chance glimpse of Wolfskehl one afternoon on George Street is the stuff of literary-historical fantasy. See James K. Baxter, "Notes on the Education of a New Zealand Poet" in: The Man on the Horse, Dunedin 1967: 121-155; 123-4.

23 See Baumberg, pp. 39-40. 
amidst the emotional uplift generated by the Dunedin experience he does not record them. Like the Steinhofs and the other Dunedin refugees, Wolfskehl was now in a city whose established Jewish citizens in their experience of the "Galut" had travelled from Europe, often in several stages, to the extreme southern edge of the world. There is no established Jewish community anywhere living further from Jerusalem than that of Dunedin. Although the city's second synagogue, an imposing building consecrated in 1881 with seating for 600 and fronted by six Doric columns, still stood in Moray Place (opposite View Street) in the very heart of Dunedin, it now served a much diminished congregation. In Dunedin, as elsewhere in New Zealand, the very low percentage of Jews in the local population had increased the pressure to assimilate. Religious law was interpreted very liberally by the majority of the congregation and synagogue attendance was relatively low. The number of Dunedin residents identifying themselves as Jewish had reached its peak in the last quarter of the nineteenth-century at 37424 and had been steadily declining as its members died or, as a consequence of the relative decline in the city's economic fortunes since the $1890 \mathrm{~s}$, moved on in search of new business or professional opportunities. This decline continued until a significant number of German- and Austrian-Jewish refugees began arriving in the later 1930s. The 1936 census yielded a resident, confessionally Jewish population of $173(0.211 \%$ of a total population of 81,848$) .25$ A list contained in the Jewish Congregation Collection in the Hocken Archives, Dunedin, relating to refugee affairs 26 indicates that some 94 Jewish refugees, 77 adults and 14 children, had reached Dunedin by June of 1940. A conservative estimate would put the population of the resident Jewish community in 1940 at some 160 persons. The arrival of the refugees increased the size of the Jewish community in Dunedin by just under two-thirds to ca. 250 persons, a figure which provides a fair indication of the size of the total community at the time of Wolfskehl's visit early in 1941.27

24 Baumberg, p. 7. Maureen Kate Cooper, indicates a peak of 428 in 1878 , but this figure should be treated with caution. See M. K. Cooper, The Jewish Kehilah in Nineteenth Century Dunedin. A Cultural and Economic Contribution, 1860-1914, B.A. Honours thesis, Department of History, University of Otago, 1986: 1. See also population table p. 10: 1864: 428; 1878: 428; 1891: 353; 1901: 311.

25 Baumberg, p. 8 (Table 3).

26 Untitled folder, Box 2, Dunedin Jewish Congregation Collection 82/89, Hocken Archives, Dunedin (hereafter DJCC).

27 Baumberg explains the statistical invisibility of this group. There was no 
More than half of Dunedin's Jewish refugee population was made up of German- and Austrian-Jewish doctors and dentists and their families who had been forced to take up residence there for the three years of compulsory retraining required of them after 1938 by the British Medical Association. The remainder represented a mixture of commercial and professional skills. Ann Beaglehole has documented the suspicion, hostility and professional jealousy displayed by the BMA at the national level towards the refugee doctors after their arrival in New Zealand.28 Pressure from the BMA effectively blocked the admission of further refugee doctors to the Medical School after 1939. In Dunedin, some representatives of the Otago Medical School, however, were ethically opposed to the lobbying of the BMA against the refugee doctors and were generally supportive of the rights of those finally admitted to the retraining programme. ${ }^{29}$ Most of the refugee dental and medical

further national census until 1945 by which time the number of Dunedin residents identifying themselves as Jewish had fallen to 153. In the intervening years the greater proportion of Jewish refugees, some two thirds, "had come and gone from the city. In 1951 R. A. Lochore set the number of Jewish refugees living in Dunedin at 37 adults, a figure, accurate in itself, but which, as the only published statistic relating to the Dunedin refugees, has until now served to mask the actual size of Dunedin's Jewish refugee population between 1938 and 1945. Baumberg, p. 10.

28 Ann Beaglehole, A Small Price to Pay. Refugees from Hitler in New Zealand 1936-46, Wellington 1988, pp. 78-81.

29 An example is provided by the case of Dr Reichmann, "des sympathischen Hundeeigners und originellen Dauerdurchfallers R.", whom Wolfskehl recalls meeting in his letter to the Steinhofs of 28. 4. 1941 (BaN I: 91). Reichmann was experiencing difficulty with the University Council in Wellington with regard to the completion of his certification. In the opinion of the University Council's external examiner in Wellington, Reichmann had failed to pass his fourth-year examination in Pathology and had initially failed an earlier section of the course, a difficulty Benson attributed to the fact that Reichmann was somewhat older than the other refugee doctors on the course and not to any lack of prior medical training or ability. Correspondence between the Auckland and Dunedin Branches of the NZJWS concerning Reichmann's case also points to an obstacle of quite another variety which Reichmann was facing:

Actually the University Authorities [Otago Medical School] have desired to pass him but the University Council in Wellington were opposed to same.

I regret to state that there is every indication that the external examiner who failed Dr. Reichmann (the internal examiner passed him) appears to have a strong prejudice against Dr. Reichmann and apparently nothing that the University Authorities can do can over-ride the decision of the 
practitioners had completed their courses by the end of 1943 and had left Dunedin to go into practice in other parts of New Zealand. 30

Beaglehole has characterised the typical experience of Jewish refugees in New Zealand in the following terms:

Refugees in wartime New Zealand met hostility, intolerance and kindness, not necessarily in equal measure. Their experience with the authorities, with neighbours, with colleagues, with shopkeepers, with people in cities and smail towns, demonstrate that New Zealand offered the refugees escape from the extreme manifestations of nazism and fascism but was not necessarily a sanctuary from anti-Semitism and minor harassment. ${ }^{31}$

There is nothing to suggest that in this respect the experience of the Dunedin refugees was markedly different. Speaking as a nonobservant Jew from his own socially privileged experience of the Dunedin Jewish community in the 1920s and 1930s, Charles Brasch conceded that some latent anti-Jewish prejudice existed in New Zealand but contested that it was "not overt in Dunedin."32 The steady arrival of refugees in Dunedin, the virulent press campaign waged against the "Jewish doctors" which utilised such front-page incitements to racial prejudice as "N. Z. Doctors Perturbed. Jews To Jump in While on Active Service" 33 and the outbreak of war chan-

appointed examiner. Professor Hercus strongly advises that Dr. Reichmann be given the opportunity of re-sitting his Pathology examination in May.

[...] the leading Professors at the University here have a high opinion of Dr. Reichmann's knowledge and the Dean [of the Medical Faculty, Dr. Hercus] has already permitted him to start his 5th year just as if he had fully passed the 4 th yard [sic] examination.

The efforts of the Dunedin Branch of the NZJWS and the Faculty of the Otago University Medical School in support of Reichmann happily met with success and by the end of 1941 he was able to enter into a Health Department medical practice at Karamea on the West Coast of the South Island. (G. Benson to H. C. Moses, 12. 3. 1941, untitled folder, Box 2, DJCC.)

30 Correspondence and other material relating to the activities of the Dunedin Branch of the New Zealand Jewish Welfare Society (Untitled folder, Box 2, DJCC) provide considerable evidence on the situation of the refugee doctors and dentists and their families. See also Baumberg, pp. 58-74.

31 Beaglehole, p. 99.

32 Charles Brasch, Indirections. A Memoir 1909-1947, Wellington/Oxford/ New York 1980, p. 110. 
ged the attitudes of some and contributed to the overt instances of anti-Semitism encountered by the Dunedin refugees whose experiences have been recorded. 34

The reasons for the existence of tensions between Jewish refugees and established Jewish communities during this period are by now comparatively well understood. Relationships between the established Jewish community and the new arrivals in Dunedin appear to have conformed largely to the variable patterns of acceptance, genuine kindness, practical charity, conflict, mutual misunderstanding, confusion and resentment revealed by Beaglehole. ${ }^{35}$ Between the experience of the long-established immigrants and the harried exiles there existed a gulf which only relatively few from either side could successfully negotiate. Social interaction between the two groups in Dunedin was limited. Wilfred Simenauer, the son Dr Maximillian Simenauer, a German-Jewish dentist from Gleiwitz who reached Dunedin in 1937, recalled " a certain coolness" from the side of the resident Jewish community and could recollect only one occasion when his family was invited to visit a local Jewish family in their home. $36 \mathrm{He}$ also recalled that, in his view, some of the Dunedin refugees fell into the trap of adopting an attitude of superiority towards other refugees and towards both Jewish and non-Jewish members of the local community. As in Auckland and Wellington, the Dunedin refugees during the war years at least, tended to remain largely confined within their own immediate circle. There were, of course, exceptions and it is to some of them that Wolfskehl was introduced by the Steinhofs.

Wolfskehl's experiences of the established and refugee Jewish communities in Auckland had been very mixed and by 1941 had already left some bitter traces. The resident Jewish community in Dunedin was certainly as marked by differences in temperament, social class, forms of employment, personal interests and attitudes

33 New Zealand Truth, 17 January 1940, p. 1. The Secretary of the Dunedin Branch of the DJWS, Gerald Benson, cites this article in a letter of 20.1.1940 as "harmful and unjust propaganda against the unfortunate Jewish Refugee Doctors". Untitled folder, Box 2, DJCC.

34 Both Wilfred Simenauer (telephone interview with SR, 23. 3. 1998) and Paul Oestreicher (interview with SR and Christine Baumberg, 27. 4. 1998), for example, recalled experiencing the anti-Semitic and anti-German behaviour of New Zealanders during their wartime school days in Dunedin. Oestreicher noted that the manifestation of these prejudices worsened in the years immediately after the end of the war.

35 Beaglehole, A Small Price to Pay, pp. 63-67.

36 Telephone interview with Wilfred Simenauer, 29. 3. 1998. 
to matters of religious observance as the Jewish communities in New Zealand's other main centres. But it was also a community which despite its falling population had maintained a degree of historical continuity and could look back with particular satisfaction on its achievements since its modest beginnings during the Otago gold-rush of the early 1860s. Perhaps because of Dunedin's geographical isolation, its smaller and more densely concentrated Jewish population, the prominence and non-partisan publicspiritedness of some its Jewish citizens like Willi Fels and Samuel Saltzman, their sense of being citizens in a city proud of its cultural traditions, their own interests and attainments in the cultural sphere, their links with the academic community, including the School of Medicine, and the existence of a considerable network of family ties with Germany, a core group of its active members were also arguably able to act very effectively in assisting a number of the refugees.

Alongside clear indications in Dunedin of the difficulties experienced by Jewish refugees elsewhere New Zealand and of a lack of extensive social contact with the established Jewish community, evidence exists which suggests that the Dunedin refugees enjoyed somewhat greater practical and charitable support from a section of the established community than elsewhere in New Zealand. The same Dunedin Congregation Committee which had brought the Steinhofs to Dunedin, in part to attend to the needs of a congregation expanded by the arrival of the refugees, had also formed a sub-committee, the Dunedin Jewish Welfare Society Committee, to deal with refugee affairs in Dunedin. The sub-committee, which became the Dunedin Branch of the New Zealand Jewish Welfare Society, faced the ongoing need to help refugees establish themselves, to assist those who lost their positions or livelihood in Dunedin after the outbreak of war and to provide loans to support refugee doctors and dentists who were effectively prevented for three years from being able to support themselves. Although the local Jewish community appears statistically quite sizeable around 1940 , in reality the burden of providing the substantial sums required fell upon the shoulders of a very small group. ${ }^{37}$ In their unstinting efforts through the agency of the Dunedin Branch of the New Zealand Jewish Welfare Society to meet the many material needs of the refugee community which began to form in Dunedin from 1938, this small but notable section of the resident Jewish

37 See Baumberg, pp. 60-69. 
community displayed a laudable degree of unity and determination during the crisis years. In his role as Secretary of the Welfare Society Committee throughout this period, and considering the very limited means at his disposal, Gerald Benson proved a deeply caring and infinitely painstaking organiser of Jewish refugee affairs, at both the local and national level. Among those refugees he was in a position to assist, there were many who later wrote expressing their heartfelt appreciation of his devotion to his task. Benson's intelligent and compassionate approach spared a number of the Dunedin refugees much additional suffering. In 1941 at least, Wolfskehl may well have gained through the Steinhofs the impression that he was in contact with a Jewish community which functioned somewhat more cohesively than that which he had encountered in Auckland.

Part of the attraction of the Steinhofs for Wolfskehl may have stemmed from the fact that their sense of displacement in New Zealand was as extreme as his own. Given Cäsar Steinhof's Orthodox background, it is reasonable to assume that he would have viewed the conduct of services and his cheder teaching in Dunedin as expressions of a concern to do everything possible to advance the level of Jewish religious knowledge: an attitude of willing compromise with secular New Zealand culture even amidst the trials of exile and under wartime conditions could hardly have been expected of him. A close reading of a number of entries in the minute book of the Committee suggests that relations between Steinhof and the Jewish congregation in Dunedin were characterised by a marked difference in approach to matters of Judaic law. As an Orthodox Jew conscious of his place in the family's Eastern European rabbinical lineage, Steinhof must have been made to feel at times somewhat uncomfortable serving a congregation made up almost entirely of Jews of German descent, who, even in those cases where the families had remained religiously observant, were still among the most liberal of Reform Jews. Among the resident community in the 1940 s there were no more than half a dozen individuals including the Steinhofs who maintained Orthodox practices. ${ }^{38}$ The vast majority of the Dunedin refugees were also German and Austrian Jews of middle-class; professional standing who had long regarded themselves as assimilated. Few were inclined to attend synagogue services regularly, even though some maintained social contact with the congregation and sent their children to

38 See Note 41. 
Hebrew School.39 Although the decision to employ Cäsar Steinhof appears to have been well considered by the Congregation Committee, there were latent sources of tension. He had effectively displaced the incumbent Reader and Sabbath School teacher, a refugee who had been active in the Dunedin Jewish community since 1938 and who was from all accounts well-liked. Efforts on Steinhof's part to move the congregation towards more strictly orthodox forms of observance at the time would have met with the understanding and approval of only a few.

In 1940 entries begin to be made in Hebrew rather than English in the congregation register. 40 Steinhof's request to the Congregation Committee in 1941 for assistance to qualify as a "Schekta" (shohet), indicative of his concern over the state of local knowledge and practice of Jewish law, was declined.41 Around September 1941 Steinhof must have applied to the Congregation Committee for recognition as a 'Reverend' (rabbi) but its members determined that the congregation was not prepared to acknowledge him as anything other than as a Reader and Sabbath School teacher. There are no signs in the minutes of any dissatisfaction with the way Steinhof carried out his assigned duties, only of resistance to any moves towards stricter observance of Jewish law. The Steinhofs's manifest Orthodoxy was quite as foreign to the majority of the refugees as it was to the resident community. ${ }^{42}$

39 See Baumberg:, pp. 42; 45-46.

40 Baumberg, notes from E. Friedlander Collection.

41 Baumberg, notes from E. Friedlander Collection. The only surviving evidence of fully kosher kitchen arrangements in a Dunedin Jewish home is to be found in 'Olveston', the house of the Orthodox Theomin family. The family of $\mathrm{Mr} \mathrm{E}$. Friedlander also observed the dietary laws. SR and CB interview with E. Friedlander, 30. 3. 1998. Baumberg presents evidence of very limited demand for kosher meat by a few other Jewish families in Dunedin in the late 1930s and of measures taken by the Jewish congregation under the Rev. Karwan (1936-1938) to ensure its availability. Baumberg, pp. 30-31.

42 According to Wilfred Simenauer his father was one at least among the refugees who now felt the need to support moves towards stricter observance of Jewish law and approved of Steinhof's Orthodoxy. As one of Steinhof's Bar Mitzvah candidates from the 1940s, Wilfred Simenauer recalled his former teacher as an unfriendly and uncompromising "fanatic" who tormented him and the other children in the Sabbath School with Hebrew texts they neither understood nor even wished to understand, a strange man who called in his Gentile neighbours to turn the electric lights on and off on the Sabbath and tied his handkerchief to his belt before the Sabbath to avoid the labour of pulling it out of his pocket. While these comments represent the perspective of a young German Jewish refugee who was extremely anxious to be accepted as "normal" by his New Zealand peers and who deeply resented his father's efforts to reinforce his sons' Jewish self- 
When he finally left Dunedin ostensibly on a short period of leave to visit Australia and did not return, Cäsar Steinhof created a minor scandal which brought to his wife, left alone in Dunedin with three young children and forced by illness to spend time in hospital, an unexpected form of suffering:

One thing after more than four $1 / 2$ years I can never forget and forgive myself: (Perhaps that gave the bitter drop to New Zealand?)

A letter arrived from Sydney: "We urgently need you as Director of Jewish Education in Sydney. You were highly recommended. Tickets will follow next week." So my husband - all doctors with families had left - left Dunedin - hoped to return after three months! - but he never did. What a disgrace! My husband too proud to tell me the truth, perhaps he did not know himself! The cottage was taken away the same week, the small salary too, and I waited for three months.

I was suddenly an outcast.

It was a dreadful time!

The departure of the majority of the Jewish refugee families from Dunedin by the end of 1943 was most likely a motivating factor in Cäsar Steinhof's decision to take the position in Sydney. His Orthodoxy was another. In Sydney he could live and work in a Jewish community which included a significant number of Orthodox Jews and more adequately fulfil there his inherited duty of teaching Jewish law:

Und so werde ich denn versuchen, was meine größere Pflicht ist, die Kinder unseres Volkes zu warten, zu lehren und zu lenken wo immer nur möglich. Ungeheuer ist die Arbeit, und nur die tiefste Liebe zum jüdischen Kind kann mir die Kraft für diese komplizierte schwierige Aufgabe geben. ${ }^{43}$

Cäsar Steinhof died of hepatitis in Sydney in 1954.

The Steinhofs' removal to Dunedin clearly did nothing to diminish Wolfskehl's delight in their company when he finally joined them there. Some weeks after his return to Auckland he again confirmed to them his need for such deeply human exchange and the imme-

identity, they nonetheless highlight the alienness of Orthodoxy in the Dunedin context. Telephone interview with Wilfred Simenauer, 29. 3. 1998.

43 Letter from Cäsar Steinhof to KW, 30. 6. 1944; BaN II, p. 344. 
Wie lang hatte ich mich hierin, in einem Wesentlichsten, zu bescheiden gehabt. Manchmal kam ich mir vor wie ein zum Platzen gefüllter Ballon. [...]

Freuen soll man sich, und wie sehr tu ichs, dass es dennoch immer wieder so etwas gibt wie lebendigen Austausch, dass der innere Drang, sich mitzuteilen, immer wieder einmal aufs Schönste befriedet wird, dass, mit einem Bilde auszusprechen, jene unvergesslichen Abende mit Euch und die nie endenden Nachtgespräche mit Dir, Cäsar, ihre beste und eine so vielseitige Fortsetzung gefunden haben in jener unvergesslichen Dunediner Zeit. Ja, das waren Wochen, in denen meine saftigsten Jahre aufzuleben schienen, fast hätt ich gesagt aufzuleben drohten! Jeder Tag gab ein neues Versprechen und war eine neue Erfüllung - und jede Nacht welch ein Ausstrecken auf herrlich langer Lagerstatt! Heut noch, nach fast zwei Monaten, ist mir zumut, als wär ich noch unter Euch, als wiegt ich den werdenden Maurice Charles in einem etwas ungefügen Arm, als fleht ich, gelegentlich fast ungeduldig, die übersorgliche Walterin Hanna an, endlich vom Herd zum selbstbereiteten Mahle zu kommen und zu einigem Aufatmen. 44

After hosting Wolfskehl for several weeks in their small house, one can well imagine that it was with feelings of sadness tinged with relief that the Steinhofs farewelled him when he left Dunedin for Christchurch around the middle of February.

While their Orthodoxy distinguished the Steinhofs from the other exiles with whom Wolfskehl came in contact in Auckland and Dunedin, their social background and level of education linked them to the cultural values of the Bildungsbürgertum. This served to initiate meetings between Wolfskehl and other Jewish refugees in the city who, although considerably younger and temperamentally little inclined to aestheticism or Dionysian excess, were like Wolfskehl, German middle-class liberals who even in exile remained essentially committed to the cultural values of their class. In Dunedin in January 1941, Wolfskehl encountered fellow emigres from Germany and Austria, and very likely some members of the local Jewish community as well, whose social and cultural background allowed him to enjoy over a period of weeks a depth, intimacy and intensity of social, intellectual and cultural exchange which became the "point of adamantine fire" in his New Zealand exile.

$44 \mathrm{KW}$ to Cäsar and Hanna Stanton (Steinhof) 28. 4. 41, BaN I, p. 90. 
Certain features of Dunedin's cityscape served to enhance the experience. If, as appears to be the case, Wolfskehl stayed the entire time with the Steinhofs and not at a "hotel" as Felix Grayeff later noted in his autobiographical sketch, 45 he would have been able to walk down from there to the city past one of the grandly appointed houses belonging to two of the city's more patrician Jewish families; "Olveston", the four-storeyed, Jacobean-style house of the Orthodox Theomin family at the corner of Cobden Street and Royal Tce, or "Manono", Willi Fels's house with his rich and carefully tended garden on its London Street side, described in a commemorative poem by Fels's grandson, Charles Brasch as

\section{A precinct green and calm}

Where climates, continents, civilisations mingled

And for a leaf-framed listening Apollo

The bellbird lingered over its flawless phrases [...].46

The scale and distinctive architecture of these residences and similar houses in and around Dunedin's Royal Terrace, and the contrast they formed with the generally less imposing houses Wolfskehl had experienced in Auckland would certainly have contributed to his strong sense of being somewhere more like Basel or Zurich. 47

A reconstruction of Wolfskehl's other encounters in Dunedin begins with the need to decode as far as possible the references made in his letter of April 1941 to the Steinhofs to a number of the figures he met through his association with them. The tone of this letter is one of blissful, culinary recollection:

Und so vieles kommt mir in den Sinn, die netten und die unver meidlichen Abende, und die im engsten Verein, und dann die ganz herrlichen mit den prachtvollen G.'s, die zu kennen ich als einen der Lebensgewinne in später Stunde betrachte. Wie nah ist mir das alles, wie gegenwärtig, wie geliebt! Und die entzückende Hügel landschaft! Und die Bücher und Zweithänder. Halt, ich schulde ja noch fünf Schillinge für die Maori-Axt, die sogar der für Insular objekte sonst unempfänglichen Margot einigen Spass machte.

45 Felix Grayeff, Migrant Scholar: An Autobiography, Freiburg i. Br. 1986, p. 53.

46 Charles Brasch, "In Memory of Willi Fels", H. D. Skinner, Willi Fels, C.M.G. 1858-1946, Dunedin 1946, p. 6.

47 See KW to Rudolf Laudenheimer, 26. 6. 1941, p. 457. 
Verzeihung der Saumsal. Wird dieser Tage beglichen. Schönen Dank für die Besorgung, lieber Cäsar [...].

Und wie steht es sonst? Ist der Honig in den Immen immer noch in der Gefahr, sauer zu werden? Und wie waltet Strudelmeister T. seines hohen Amts als Küchenchef? Und N. der Milchschäker und Selbstverfertiger gradezu essbarer »lollies«? Und, noch eine Bitte: hiesige Wiener waren geschüttelt vor Erregung als sie ver nahmen, man habe mir in Dunedin eine echte und reguläre Bisch gotentorte vorgesetzt. Sie wolltens nicht glauben, der Mund wässerte ihnen. Und wie aus einem Munde kams: »gellens, Sie verschaffen uns das Rezept für die Bischgoten! Net vergessen, bitt schön!« Dies Wunder österreichischer Backkünstlichkeit trat bekanntlich an jenem Abend im Doppelflat des rastlosen Redners F. und des sympathischen Hundeeigners und originellen Dauer durchfallers $\mathrm{R}$. zutage, oder vielmehr zu supper. Ich selber habs gar nicht so überhoch gewürdigt, und die gleichzeitig erscheinenden Kipferln sprachen mich weit freundlicher an. Aber, wie gesagt, die Wiener sind wild auf ein Rezept für Bischgoten, nur für diese selbst, wie man das Tortenwerk aus ihnen errichte wüssten sie eh. Also, wenns die Gelegenheit gibt, erfragt das Geheimnis und gebts mir freundlich weiter [...]. 48

Traces have come to light of some of the providers of the comestible, social and cultural delights fondly recalled here by Wolfskehl. "Strudelmeister T." was Dr Hans Tritsch, a Jewish refugee from Vienna, "a Doctor of Law and a Judge of the Supreme Court, Austria" who together with his wife, Amalia, had set up a "savoury shop" in Dunedin which they had recently been forced to close. 49 "N. der Milchschäker und Selbstverfertiger gradezu ess-

48 Letter from KW to Cäsar and Hanna Steinhof, 28. 4. 1941, BaN I, p. 91.

49 Hans Tritsch is described by Benson in an letter (unsigned) to Harold $\mathrm{C}$. Moses, 10. 12. 1943 (untitled folder, Box 2, DJCC) as "one of nature's gentlemen and almost a Saint, one of the few of the refugees who was courageous enough to tackle anything to make an honest living for himself and his Wife. He took some lessons in Cooking and started a kind of Delicatessen shop. He had very little money and our Society assisted him financially and his business progressed excellently until the war started. He persevered for some months and his losses eventually compelled him to close down. He subsequently took a position as Cook at a Shearing Camp and afterwards received a position as Chef at the University Students Hostel." It is presumably to this university hostel position that Wolfskehl's comment refers. Fate proved unkind to the Tritschs's savoury shop on George Street and to the humble and enterprising refugee from Vienna. Nearly a year after the meeting with Wolfskehl, Tritsch was admitted to the University of Canterbury as a student of law but, according to the correspondence found, died quite unexpectedly during an operation in Dunedin before 
barer 'lollies' " was O. Newman [Neumann], the husband of Dr Catherine Newman, who after completing her training in Dunedin, became a medical practitioner in Christchurch. In the late 1930s, Newman had taken over a sweet manufacturing business established in the 1880 s by a resident Dunedin Jewish family named Romison. At the time of Wolfskehl's visit, he was, according to his own letterhead, running a "High Class Confectionary - Milkbar" at 150 High St., Dunedin. 50 "[D]er sympathische Hundeeigner und

he could commence his New Zealand legal training: "He received this advice whilst he was in Hospital just prior to undergoing an Operation" (ibid.). His widow, Amalia Tritsch, found herself in a desperate situation. The Tritschs had many friends amongst the Dunedin refugee community. There was a very large attendance at his funeral and all the refugees who could assist financially, even those who were by then in other parts of the country, contributed what they could afford to an appeal coordinated by Benson. In his appeal letter (undated, untitled folder, Box 2, DJCC) Benson noted: "None displayed more manliness in the face of adversity nor won such esteem and affection amongst booth Jews and non Jews. It is known that his first and last thoughts were for the welfare of his wife, who is now left alone and penniless mainly amongst strangers." Benson allowed his company, Bing Harris Ltd., to provide for the storage and eventual auction of the failed business's surplus kitchen equipment which fetched a pitiful sum. Although advised against the move by friends from Dunedin, Amalia Tritsch decided to move to Auckland where she perhaps imagined an opportunity to make her way alone might be more readily accessible. A letter pledging support for her written at the time of the appeal by Dr Hans Hersch who had recently completed his Dunedin medical retraining and was practising medicine in Herne Bay, Auckland, highlights the perceived contrast between the Dunedin and Auckland communities in matters of charitable assistance of the kind required by Amalia Tritsch: "Unfortunately the community of Auckland is quite different from the Dunedin community so that $\mathbf{I}$ am afraid that she will not have a big help with them. I didn't meet any one of them here, but everybody says that they will not assist her. So we shall do our best to help her not to feel too lonely so we didn't meet many people yet to find a position for her." (H. L. Hersch to G. Benson, 7. 4. 1942, untitled folder, Box 2, DJCC.) In December 1943 Benson learned "that Mrs Tritsch was no longer able to earn her living making gloves and was in a desperate plight:" He wrote to Harold Moses of the NZJWS to alert the Auckland Branch to her position and recommended that she apply for a widow's pension admitting that there was no guarantee that she would meet the criteria. Whether Wolfskehl met her again in Auckland is not known.

50 Not long after Wolfskehl's appreciative sampling of his wares, Newman like Tritsch before him, found himself facing severe financial difficulties caused in the main by his foreignness, the need to service the initial loan, and the lower turnover and increasing overheads which resulted directly from New Zealand's entry into the war:

[...] as I could not speak English fluently, I had to keep 2 girls and the business can't afford 2 girls with the high wage of $£ 2.12$ weekly. I had made my living quite allright and as I dismissed 1 Girl about 6 months ago, I can still make a modest living, although trough [sic] the Blackout 
origineller Dauerdurchfaller R." who shared with the "rastlose Redner F." the "Doppelflat" where the "Biskottentorte" and "Kipferln" so enchantingly appeared, was almost certainly Dr Reichmann, an older physician from Vienna. F. was possibly a Dr Finkelstein. 51

Of more than passing interest is Wolfskehl's meeting with "die prachtvollen G.'s", Walter and Olga Griesbach. Although now living in much reduced circumstances as Wolfskehl's epithet suggests, the Griesbachs still moved in a somewhat wider social circle in Dunedin than the more or less unfortunate refugees with whom they share this page of Wolfskehl's recollections. Walter Edwin Griesbach had been born of Jewish parents in 1888 in New York and after the death of his German-born father had migrated to Hamburg with his family. He studied medicine at Freiburg i. B., Kiel and Munich and pursued a highly distinguished career as a medical researcher. Griesbach had completed his doctoral research, summa cum laude, in Freiburg in 1913 and served as a military doctor in the First World War. In the 1920s, he specialised in pharmacological research at the Chemical-Physiological Institute of St Georg Hospital, Hamburg, where he worked under Professor Bornstein. His research there included work on the development of insulin and in 1930 he became Professor Extraordinarius of Pharmacology at the University of Hamburg. Griesbach's teaching registration was withdrawn along with that of all other Jewish academics in March of 1934 under the provision of Paragraph 6 of the "Reichsgesetz zur Wiederherstellung des Berufsbeamtentums". From 1934 until the end of 1938 and the decision to emigrate, he worked as the medical superintendent ("Leitender Oberarzt") of the department of internal medicine at the "Isrealitisches Krankenhaus" in Hamburg.52

and Calling Up, I lost - like other shops in my line - many Customer[sic], and I am working 95 hours weekly, but I can not pay the old debts, as the Summer business was through the cold weather very quiet. I had difficulties in getting the goods as the people won't deliver any more, but I must always have the goods asked for. If I can't pay the debts till next week, I am perhaps forced to close.

Letter from O. Newman to G. Benson, Chairman DJWS, requesting help with a bank guarantee of $£ 150$, type-written, 26. 2. 1942, untitled folder, Box 2, DJCC.

51 Reichmann was among the materially most disadvantaged of the refugee doctors and dentists in Dunedin: "Dr. Reichmann possesses nothing, having had to hasten from Vienna, without either his Medical outfit or any Furniture." G. Benson to H. C. Moses, Hon. Sec. Auckland Branch NZJWS, 25. 11. 1941, untitled folder, Box 2, DJCC. See also Note 48 above. 
The Griesbachs had already left Hamburg on their way into exile when, early in 1939 at a conference in London, Griesbach met Professor Hercus, the Head of the Otago University School of Medicine. Hercus offered to ascertain for Griesbach those research areas which might still be open to him in New Zealand, namely goitre, dropsy and infantile anaemia. Griesbach found that the way to general or specialist medical practice was effectively barred to him by the three-year retraining requirement for refugee doctors. The decision not to go through this process cannot have been an easy one and observations made by some who knew him in the 1950s suggest that he felt deeply the consequent loss of the right to practise medicine. The Griesbachs must also have found extremely galling the financial restrictions imposed on them by his dependence on the very modest income available to him as a research fellow in the 1940s and 1950s. Hercus moved quickly, however, and obtained permission from the New Zealand Medical Council to appoint Griesbach to a research position without going through the usual process of checking his qualifications. At the age of 50, in June 1939 Griesbach took up thyroid research in the Thyroid Research Department at Otago. He began a second distinguished research career in what became the Endocrinology Research Department which he continued even after his official retirement on the grounds of ill health in 1961. He died in Dunedin in 1968.

The meeting with Hercus in London did not take place solely on the strength of Griesbach's considerable professional reputation nor was it just a matter of chance. Olga Griesbach was born a Hallenstein in Baroda (or Krempe) in 1897. Through her father, Henry Michaelis Hallenstein, she was closely related to members of the extended Hallenstein-Michaelis-Fels mercantile family which had radiated out from Brunswick and Pyrmont in Germany in the 1830 s to England, Australia and to Otago, New Zealand. Olga Griesbach was therefore related to a number of Dunedin's more prominent Jewish citizens, to Willi Fels and Charles Brasch amongst others, and it is hard to imagine that Hercus had set off by ship for the London conference without some prior knowledge of the Griesbachs's plight. They reached Wellington on Anzac Day in April 1939.

The "splendour" which Wolfskehl found in the Griesbachs in 1941 was now displayed in a much humbler setting than in their former

52 Biographical details from Viola A. Schwarz, "Die Forschungsergebnisse Professor Dr. Walter Edwin Griesbachs aus den Jahren 1941-1967", Skript zum Referat, Endokrinologie-Seminar in Oberjoch, 25.- 31. 02. 1994. 
Hamburg apartment but the couple carried with them an aura of personal dignity, grace, discernment and the cultural and intellectual attainments representative of the vanishing Bildungsbürgertum to which they unmistakably belonged. The richness of the Griesbachs' cultural heritage was immediately discernible to all who visited, even in later years to New Zealanders who at first had little or no understanding of the complexities of German cultural life. There were also a few outward signs of their distinctiveness. They had managed to bring with them from Hamburg some of their better pieces of furniture and a Steinway which rapidly gained the reputation of being the best grand piano in the city and possibly in the whole country. Walter Griesbach had like Adorno seriously contemplated a professional career as a musician before dedicating himself to research. His musicianship was such that he was reportedly regarded as the best amateur pianist in Hamburg and both he and Olga had been well known in musical circles in Hamburg and Berlin.53 He had acted as personal physician to a number of leading figures in the cultural life of the city, including members of the Koechert Quartet. It was a form of service which he was to extend in exile to Wolfskehl through diagnosis by long-distance telephone consultation - somewhat illegally, given his nonpractising status. Like other refugees from Europe, the Griesbachs are said to have found the local architecture bizarrely unfamiliar. The modest apartment which they occupied in Tennyson Court, one of the city's few apartment blocks, a two-storeyed Deco style building, was the nearest affordable approximation Dunedin offered to their once familiar habitat. 54 Number 8 Tennyson Court became a salon-in-exile, one of three or four focal points in the social and cultural life of the Dunedin refugees whose number included several talented amateur musicians and two professional singers, Emma Oestreicher, a "Kammersängerin" from Meiningen and Rose Simenauer, an operatically trained singer from Gleiwitz. A serious interest in music was the way in which a number of the refugees and after the war, young New Zealanders like the pianist, Maurice Till, came to enter the Griesbachs's apartment and be enchanted by what they heard there. In their Dunedin years the Griesbachs hosted many renowned musicians, among them the pianists Lily Kraus and Yalta and Hephzibah Menuhin. Walter

53 E-mail from Viola Schwarz, 4. 3. 1998.

54 Interview with June Hunter, former technical assistant to Walter Griesbach, 4. 2. 1998. 
Griesbach's effect on the medical-scientific community and the very considerable influence of the Griesbachs on the musical and cultural life of Dunedin, like that of the three or four other refugee families in Dunedin in which, what Paul Oestreicher has characterised as "the Thomas Mann syndrome" 55 manifested, cannot be fully explored here.

Those who knew Walter Griesbach in Dunedin remember him as a man of great modesty, but his extrovert personality, humanity and manifest intellectual and musical gifts inevitably impressed themelves deeply on others, and he, like Wolfskehl and Karl Popper, must be numbered among the most accomplished and influential of the exiles who reached New Zealand. Wolfskehl's characterisation of Griesbach to Laudenheimer as a "Mann von gradezu antiker Haltung, ohne jede Gespanntheit völlig durchgeistigt, dabei durchaus nah, einfach und, wie ich glauben möchte, von außerordentlichem ärztlichen Blick, Herz und Verstand" is supported by the statements of other witnesses, a number of whom not only liked and respected Griesbach but clearly revered him.56 Wolfskehl's tribute to the depth of his encounter with Griesbach is fittingly a poetic one. His framing of his own medical history for Griesbach in the poem "Medico Magistrali" (Auckland, 1941)57 - "eine gereimte Autonamnese"58- as an ironic metaphysical conceit concerning the inscription of fate on the afflicted and transient body, reflects in its construction of the reader as a deeply cultured fellow-sufferer, the high esteem in which he held Griesbach and his recognition of him as an equal and sympathetic spirit.

Wolfskehl's published correspondence points to another GermanJewish exile with whom he came into contact in Dunedin, a "Dr. F.". The longer of the two published letters to Dr. F. concerns Wolfskehl's helpful but not altogether approving response to the former's translation into English of George's poem "Jünger".59 From the

55 SR and CB interview with Paul Oestreicher, 27. 4. 1998: "the Thomas Mann syndrome - we represent the better Germany." The evidence of Paul Oestreicher and Wilfred Simenauer points to the possibility of tension in Dunedin between refugee families like the Oestreichers, Simenauers, Griesbachs, Grayeffs and Fromms who openly asserted their positive relationship to pre-Nazi German culture and maintained their Germanness in the home and those who reacted bitterly against their German inheritance.

56 Interviews and telephone conversations in Dunedin with Heidi Wassner, June Hunter, Werner Lassally, Pat Petersen and Wilfred Simenauer, 1997-98.

57 Karl Wolfskehl, Gesammelte,Werke, Bd. 1, Dichtungen, Dramatische Dichtungen, Hamburg 1960, p. 268.

$58 \mathrm{KW}$ to Rudolf Laudenheimer, 26. 6. 1941, p. 458. 
unpublished correspondence at Marbach Friedrich Voit has established that "Dr. F." was Dr Felix Grayeff. Other records of Grayeff's presence in Dunedin have since come to light. Grayeff had fled Berlin early in 1938 after his younger sister, Ellen Cassia, who had left Berlin the previous year for Australia where the family had relatives, succeeded in obtaining an entry permit for her brother. After spending some months in Australia searching for employment, Grayeff had arrived in Dunedin in February 1939 to take up a position under Professor George Thompson as assistant lecturer in Modern Languages at the University of Otago. Grayeff was to take over and eventually expand the teaching of German language and literature at Otago to the level of a full four-year MA course at which point it was able to become a separate department. His initial appointment was, however, in his own words "on a temporary basis only, to do the work of Professor Thompson's senior assistant, a lady who was then on sabbatical leave."60

Grayeff [b. Grajew] shared with the Griesbachs and some of the other Dunedin refugees an upbringing and educational background typical of the German-Jewish Bildungsbürgertum. He was first and foremost a classicist and philosopher. His knowledge of modern and medieval German literature (and of French literature) was also more than advanced enough for him to fulfil the requirements of a modern languages department in the New Zealand of the period. He had been born in Königsberg in 1906, the son of a well-to-do merchant family of Russian Jewish descent (Lithuanian or Ukrainian). Although his father and grandparents had been observant Jews, he described his mother as "less religiously inclined"61. Grayeff's father died early. His mother was left well-off and was a great lover of theatre and the arts. The new family house, a villa in a fashionable new suburb of Königsberg, became between 1911 and 1922 "a centre of social life, with leading theatre personalities as its stars. Leopold Jessner, [and] his successor Rosenhayn were her guests as well as actors, actresses, journalists, writers (Ludwig Marcuse was one of them) [...]." 62 Grayeff enjoyed the best of liberal Prussian education at the "Königliche Hufengymnasium" and went on after 1924 and a short period as a student of medicine in Heidelberg, to study classics at Freiburg i. B. with se-

59 BaN I: KW to D. F., 26. 12. 1942.

60 Grayeff, Migrant Scholar, p. 50.

61 Ibid., p. 2.

62 Ibid., p. 4. 
mesters in philosophy and classics at the universities of Vienna, Berlin, Heidelberg and Königsberg. Grayeff was the first student to complete a doctoral dissertation under Wolfgang Schadewaldt at Freiburg Untersuchung über die Bedeutung der Gebärden in der Griechischen Epik, 1934). Among his teachers in classics and philosophy were Wilamowitz, von Arnim, Jeager, Maas, Husserl, Jaspers and Heidegger. In 1925 in Königsberg Grayeff renewed his friendship with Hannah Arendt which had begun when they were eight or nine and which persisted with long intervals "till her death in 1975"63. In 1926 they travelled by train together to Heidelberg, where Arendt was studying with Jaspers. They attended many lectures together and Grayeff recollected them going of many long walks engrossed in discussion of what they had just heard.64

Grayeff took his viva under Schadewaldt in July 1930 and hoped to begin an academic career. He was fully aware how unpropitious the time was for German-Jewish scholars and "it was with forebodings rather than hope"65 with which he looked forward to the crucial interview with Schadewaldt. In spite of this foreknowledge, Schadewaldt's evasive responses at first disappointed then finally infuriated him: "he certainly never said that I was unsuitable for a university post. At some stage or other during this conversation he told me that while he personally would not mind having a Jewish assistantlecturer, many of his fellow-professors would find such an arrangement unacceptable."66 Grayeff did, however, take Schadewaldt's advice to return to Königsberg and take his Staatsexamen which would at least qualify him for a government post of some kind. In 1931 he found a temporary post at the Friedrichskollegium, once Kant's school, in Königsberg. A second attempt to pursue an academic path was frustrated, this time by a Professor of Classics at Königsberg, Paul Maas, himself a Christian of Jewish parentage, who was quite naturally already anxious about the security of his own position.67 Grayeff lost his last German state secondary teaching position at Potsdam's Victoria Gymnasium in March 1933 and from then until his flight to Australia in 1938, survived with his mother and sister in Berlin, like so many other German Jews from similar educational backgrounds, by teaching (intermediate German and elementary French) in a Berlin synagogue school. It was

\footnotetext{
63 Ibid., p. 13.

64 Ibid., p. 25.

65 Ibid., p. 29.

66 Ibid., p. 30.

67 Ibid., p. 33-34.
} 
here that he met, Marianne Zander, his future wife, who did not reach Dunedin until 1943. (Their marriage was solemnised in Dunedin by Cäsar Steinhof late in 1943.) During the Berlin years Grayeff continued his "linguistic and historical studies, now with a strong leaning towards subjects of Jewish interest." 68 He wrote and published on Hellenistic history, translated Ezekielos's tragedy Moses and in 1934 published with Schocken in Berlin his translation into German of the apocryphal First Book of the Maccabees. 69 Grayeff's academic progress was cruelly interrupted by events in Germany but his publications in classics, philosophy and history from the time he arrived in New Zealand and later in Great Britain were well regarded by his academic peers and are still considered to be of scholarly value. In 1953 at the invitation of Gottfried Martin, he became an editor of the revived Kant Studien in which he also published. He later published a notable study of Aristotle and his school.70

In Dunedin Grayeff's engaging intelligence and open-mindedness soon saw him on good terms socially as well as academically, not only with George Thompson but also with a number of other, especially older and highly cultured colleagues including the Professor of English, Herbert Ramsay, and the Professor of Surgery, Renfrew White, who, together with his wife, Ida White, was very active in musical circles in Dunedin. At the time of Wolfskehl's visit in 1941 Grayeff would have been enjoying the summer vacation before the commencement of his third year at Otago. The University Calender for that year indicates that he was occupied with preparations to introduce new course elements in German Romanticism, phonetics and German conversation together with a programme for German science reading.

Grayeff's posthumously published autobiographical sketch Migrant Scholar: An Autobiography contains a brief account of his meetings with Wolfskehl:

68 Ibid., p. 42.

69 Der Freiheitskampf der Makkabäer, aus dem 1. Makkabäerbuch übers. v. F. Grajew, Berlin 1934 (Jüdische Lesehefte 4).

70 See, for example, Felix Grayeff, The Political Organisation of Peace. Two Essays, Dunedin 1941; Deutung und Darstellung der theoretischen Philosophie Kants: Ein Kommentar zu den grundlegenden Teilen der Kritik der reinen Vernunft, Hamburg 1951; Heinrich VIII: Das Leben eines Königs - Schicksal eines Reiches, Hamburg 1961; Aristotle and his school: An inquiry into the history of the peripatos; with a commentary on Metaphysics $Z, H, L$ and $Q$, London 1974. 
Karl Wolfskehl, once a member of the Stefan George circle, had recently arrived in New Zealand from Italy. He had made his home in Auckland but in 1940 [sic] he visited Dunedin where he had friends - immigrants like himself - and I was introduced to him. He was nearly blind by then and as I took him from his hotel to his friends or to a park where he wished to rest, we had many conversations $[\ldots]^{71}$

It is most likely that Grayeff was introduced to Wolfskehl by the Steinhofs who were among the Grayeffs' close friends in Dunedin.72 With Wolfskehl Grayeff recalled talking "about S. George, F. Gundolf and above all the principal characteristics distinguishing English poetry from German."73 It was Grayeff who introduced Wolfskehl to Ramsay ${ }^{74}$ in whose house Wolfskehl enjoyed some "informative talks" and with whom he also later corresponded.75 Ramsay's extensive knowledge of and intriguing theories about Shakespeare's works interested Grayeff deeply enough to become the almost exclusive subject of their regular Saturday afternoon get-togethers at Ramsay's house. With Wolfskehl, however, Ramsay was drawn to talk about Swinburne:

To my surprise he [Wolfskehl] admired Swinburne and indeed, when I took him to meet Professor Ramsay, it was Swinburne Wolfskehl and Ramsay almost exclusively discussed, admitting their great liking of Swinburne's work to each other without, however, by any means overestimating Swinburne's rank an a poet. 76

This is one of several positive echoes which Wolfskehl's interest in Swinburne found during his New Zealand exile.

The tone of the published extracts from Wolfskehl's letters to Grayeff is more formal and emotionally restrained than his communication with the Steinhofs and reflects in part his response to Grayeff's more introvert personality. His words are nonetheless appreciative of Grayeff's intellectual capacities and in 1942 he is hopeful of further exchanges on subjects of mutual interest.77

71 Grayeff, Migrant Scholar, p. 53.

72 Letter from Marianne Grayeff to SR, 12. 6. 1998.

73 Grayeff, Migrant Scholar, p. 53

74 Professor Herbert Ramsay, M.A. St Andrews, had been Professor of English at Otago since 1921.

$75 \mathrm{KW}$ to Ramsay, 24. 3. 1941, DLA.

76 Grayeff, Migrant Scholar, p. 53. 
Grayeff is still warmly remembered by many of his former students. He was a very private man, little inclined to talk with them about his German university days, his struggles after 1933, or his other interests, reserved and quite formal in lectures. He set exacting standards of scholarship based on his belief in "Akribie". Yet he is also remembered as a kind and fair-minded lecturer, who was particularly understanding of the difficulties experienced by young New Zealanders in striving to master the intricacies of German vocabulary and syntax. A former student, Maurice Andrew, experienced Grayeff as a challenging and intellectually inspiring teacher. He recalled him as a "small man who walked with a slight stoop" and spoke good English with a strong German accent: "[...] he often appeared sad and sometimes dispirited. [...] Sometimes his expression took on the smile of reason which you see in portraits of figures from the Enlightenment, but he had a nervous laugh on taking leave. While lecturing, he would pass his hand over the top of his head (almost completely bald), bring it round in front, clasp his tie with thumb behind and fingers forward, and lower his hand down its full length. I learned that his main interest was Philosophy and that he had written a book on Kant, but he never gave the impression that he was skimping the German he taught us."78 Paul Oestreicher, who completed a BA in Political Science at Otago in 1953, also studied German with Grayeff for three years. He enjoyed the additional benefit of knowing the Grayeffs privately through his parents: he encountered in Felix Grayeff a genuine "polymath" and a mentor who helped to foster his intellectual development. ${ }^{79}$ Andrew, who went on to study theology in Germany, writes too of Grayeff that "he aided my flight into scholarship and humanity." 80

In his autobiographical sketch, Grayeff noted after the death of Professor Thompson in 1944: "I sensed a changed atmosphere around me. In the end, I felt that I had to leave my university post in New Zealand and return to the old world with my family and

77 In an unpublished extract he enters into more personal details: "Aus meinem Aufenthalt in Christchurch wurde damals nichts, da ein ziemlich heftiger Herzanfall mich zunächst ans Haus und dann auf lange hinaus noch in eine karge Lebensform voller Vorsicht und Behutsamkeit bannte, und eigentlich immer noch meine Schritte wie auch meine Tätigkeit hemmend bestimmt." KW to Grayeff, 26. 12. 1942, DLA.

78 Maurice Andrew, manuscript of unpublished autobiography, p. 114.

79 P.O. interview with SR and Christine Baumberg, 27. 4. 1998.

80 Andrew, p. 190. 
settle there".81 And in the "Epilogue" he states that "following a series of happenings, of which I will give no detailed account in this context, I had been looking even more eagerly for an opportunity of leaving New Zealand".82 Grayeff was remembered by some who encountered him only just before he left New Zealand with his family in 1952 and knew little or nothing of his background, as a man who for some reason "had a chip on his shoulder" and who had become somewhat uncooperative with the university authorities over questions concerning the teaching of modern German literature. 83

Grayeff's difficulties at the university after 1944 appear to have arisen from two principal causes: his efforts to advance his professional career and his German-Jewish ethnic and cultural identity. University records show that in the thirteen years he spent at the University of Otago Grayeff remained throughout at the level of Assistant Lecturer. Given his extremely high level of qualification, his obvious competence and the fact that he was responsible for teaching the entire German degree programme, the repeated refusal to grant him the more senior status of full lecturer appears surprising. From 1946 he sought clarification of the status of his position. Already forty years old, it must have been clear to him that if he could not advance in Modern Languages at Otago, he would have to gain an academic position elsewhere very soon or his academic career would founder. Supporting a family on the meagre salary of an assistant lecturer must also have created added pressure. There was also the question of his research orientation. In his application to the university he had also signalled his availability for a position in classics and in the late 1940s was working to complete his book on the central part of Kant's Critique of Pure Reason. 84 With a very full teaching load, without access to leave and denied the possibility of advancement, his assessment of his professional situation became increasingly desperate. Grayeff's political essays demonstrate his commitment to principles of reason, decency, justice and equity. He presented his case for advancement and leave in an open and forthright manner. He had after all come to New Zealand from Australia before the outbreak of the war having accepted a legitimate offer of academic employment and had

81 Grayeff, Migrant Scholar, p. 50.

82 Ibid., p. 68.

83 Letter from Rex Barrell to SR, 24. 6. 1998.

84 One informant remembered him primarily as a philosopher who was very active in philosophy discussion groups in Dunedin. 
every reason to expect that he would be permitted to advance his career like other members of staff. Experience proved otherwise.

In an essay written in Dunedin 1950 by a Scottish academic who had worked with the Jewish community in Hungary between 1935 and 1939, concern is expressed over the prevalence of anti-Semitic sentiment in New Zealand and the presence of the "Green Plague [...] the disease of jealousy" which in his view were manifesting as a series of commonly held resentments against Jews.85 Grayeff acknowledges that from the outset he also had his "adversaries", some of whom he knew to be opposed to his appointment "on principle".86 What he does not state in his autobiographical sketch is that the "senior assistant" whose work he was to take over was spending some months of her sabbatical leave in 1939 in Munich. According to one informant this circumstance had dire consequences for the unsuspecting refugee from Berlin:

[...] it seems certain that the beginnings of his difficulties at the University of Otago were due to the fact that the Senior Assistant at the Department of Modern Languages had spent several months of her Sabbatical Leave (in 1938 or 1939) in Germany where she came under the influence of the Nazis. On returning to Dunedin she was very displeased to find a new member of the staff in the Department who was a Jew. Her immediately unfriendly attitude towards Felix never changed. She had some like-minded friends at the University who after Professor Thompson's retirement and subsequent death became very influential. 87

85 George A. F. Knight, The Jews and New Zealand, Christchurch 1950, p. 8. Knight, who arrived in 1949, observed: "First, I find men and women in this the Antipodes of Nazi Europe who have never met a Jew, but who know all the Nazi half-truths about the Jew off by heart, and I realise that while the armies of Hitler have indeed been overthrown, the spirit of Hitlerism has conquered the hearts of men in many lands" (11).

86 Grayeff, Migrant Scholar, p. 51.

87 Letter from Grayeff's widow, Marianne Grayeff, to SR, 12. 6. 1998. The senior assistant and later senior lecturer in the Modern Languages Department to whom she refers but does not name, was Vida Barron (1879-1974). In 1939 she spent some months at the Munich University. See Jane Thompson (ed.), Southern People. A Dictionary of Otago Southland Biography, Dunedin: 1998: 27. Oestreicher confirms that she was actively hostile towards Grayeff. Telephone interview with P. Oestreicher, 27. 1. 1998. Whether Grayeff was actually instructed to include in his course texts by pro-Nazi authors as both informants claim, cannot be ascertained, although records indicate his refusal early in 1952 to teach what he described as "Nazi literature." 
The full extent of any opposition from within his own teaching area to his continued presence on the grounds of his ethnicity is now impossible to gauge. What is clear is that with Thompson gone Grayeff's case for advancement was not supported by his immediate superior. By 1946 he was already facing the possible termination of his employment by the end of the following year. The issue which finally resulted in 1952 in Grayeff being strongly advised to agree to resign, centred on an escalating dispute over his objections to teaching those sections of a new national course prescription for modern German literature introduced in 1948 which required him to deal with the period of the rise of Nazism and examples of "Exilliteratur". For four years from 1948 until 1952, his students recall that Grayeff taught a range of twentieth-century authors in his courses including poems by Wolfskehl. Behind the scenes, however, he voiced his criticisms of the choice of the modern period to the syllabus committee in Wellington expressing concern over the literary quality of some of the works chosen and the suitability to younger students of works which drew on "Freudianism". In this he found some support. What was perceived or presented at the official level as a lack of cooperation over syllabus matters masked another dimension: the invisibility of Grayeff's Jewishness within the institution and in the wider New Zealand context of his exile. In a final attempt to persuade the university authorities to allow him to teach an alternative period, he repeated his formal objections to the curriculum decision and then added tellingly on the years after 1918: "I need not say that it would be painful for me to lecture on the German literature of this period, or on the history of the emigre writers, many of whom committed suicide in foreign countries." 88 Grayeff's authentic voice, that of a German Jew who had narrowly escaped the Shoah, who like Wolfskehl and other exiles in New Zealand had been deeply depressed by news of the murder of family members, was drowned out by an uncomprehending institutional discourse which in its Anglo-Saxon Christian monoculturalism could deal only with the "ideal" (and finally nonexistent), fully assimilated and hence thoroughly invisible Jew. His open reference to his Jewishness as the source of his difficulty in what was officially regarded an "objective" academic matter was an embarrassment which threatened to subvert the authority of the discourse. Trapped after years of dedicated service in a position

88 Submission from F.G. to Dr Aitken, University of Otago Vice-Chancellor, 16. 4. 1952. 
which now clearly offered no prospect of advancement among colleagues who were at best indifferent and at worst hostile towards his continued presence, Grayeff acted to rescue his career and his threatened subjectivity and provoked the prompt termination of his employment. Technically he left for Britain with his family on leave of absence but both sides had agreed that he would not return to Dunedin. Grayeff's last lecture at Otago was on Peter Schlemihls wundersame Geschichte. ${ }^{89}$

In a photograph belonging to Hanna Urmann, Wolfskehl appears with a short, immaculately dressed, white-bearded figure who closely resembles portraits of the prominent Dunedin Jewish businessman, collector and Otago Museum benefactor, Willi Fels. The rugged landscape in which the two figures are posed and the glimpse of a car to their left strongly suggests that Fels may have had Wolfskehl and himself driven to one of the Maori archaeological sites at Little Papanui, Murdering Beach or Long Beach on the Otago Coast where he was endeavouring to master the technique of surface collecting. Fels may also have been the source of or the adviser on the Maori axe whose purchase Wolfkehl refers to in a letter to the Steinhofs (28. 4. 1941). There are a number of reasons for seeking to establish that a meeting between Wolfskehl and Fels actually took place in Dunedin in 1941.

Fels was born in 1858 in Halle, was a nephew of Bendix Hallenstein and in 1881 in Pyrmont, Germany, had married his cousin, Bendix Hallenstein's eldest daughter, Sara. He had reached New Zealand in 1888 and joined the head office of Hallenstein Brothers in Dunedin. As a young man he had hoped to pursue an academic career in history and classics and maintained a lifelong interest in those areas of learning and in religious thought although he had ceased to be an observant Jew. Fels had travelled often to Europe and the Middle East. His extensive collection of book and artefacts, much of which he gifted to the Otago Museum and the Otago University Library, included not only Maori and Oceanic material but many other items that would have been of great interest to Wolfskehl, especially the Greek coins which made up nearly a thousand of the more than five thousand coins he had carefully catalogued since he began collecting them as a boy in Germany, and the ceramics and glass. Fels's library was one of the best private collections in Australasia. It included early printed books by Venetian and Dutch painters and first-editions of a number of English writers, including some rare first-editions of Swinburne and commentaries on his work:

89 Andrew, p. 190. 
Fels was almost 83 at the time of Wolfskehl's visit but was still very active and a most attentive host: "[h]e met businessmen, museum people, collectors, Maori scholars, botanists and public figures and private friends [...]."90 Among Fels's close university friends was Grayeff's friend and benefactor, George Thompson.91 It is quite possible that Wolfskehl was introduced to Fels through this connection. Fels had lost a son, Harold, and a nephew in the First World War. Since 1933 he had refused to enter Germany. He was among the more generous contributors to the relief fund established by the DJWS for the Dunedin refugees. ${ }^{92} \mathrm{~A}$ comment by Brasch on the way in which he considered Fels had succeeded in building a bridge between the old world and the new highlights the paradoxical nature of a meeting in Dunedin between the German-Jewish exile, Wolfskehl, and the Jewish migrant, Fels, within the overarching experience of the Diaspora: "I see it as Grandfather's consistent aim, always to acclimatize in the new country which as a young man he had chosen for his own the best ideals and products of older countries, especially of Europe, and above all classical Italy and Greece."93 Although his "choice" of New Zealand had been prompted by dire circumstances, Wolfskehl too had brought with him the best of the "old world", and was also making a remarkable effort to acclimatise and establish postive links with the new culture. Fels's passion for botany and history found expression in his garden at "Manono" where the shapes and fragrances of the Mediterranean mingled with native plants and trees.

He brought back seeds and plants from the many lands he visited [...]. Cyclamen, the white and the mauve, from the slopes of Etna and the Dolomites, grew well at Manono [...]. The acanthus flourished too, and asphodel and white wood-anenomes (Shelley's windflower) [...]. From the barren hills between Ceuta and Tetuan [...], he brought back the seeds of a large rock-rose with black centre, perhaps the first in New Zealand. 94

He watched growth and flowering with eager delight and he knew where every plant had come from: a gentian from the hills above Florence, a cyclamen from the ruins of the Greek theatre at Taormina; this fern from the Routeburn or that from the roadside

90 Brasch, Indirections, p. 54.

91 Ibid., p. 116.

92 List [1940] "Dunedin Jewish Welfare Society", untitled folder, Box 2, DJCC.

93 Brasch, Indirections, p. 52.

94 Ibid., p. 52. 
on the summit of Mount Messenger. 95

Wolfskehl and Fels may well have conversed in this garden briefly or at length before or after the archaeological excursion to the beach. Wolfskehl would certainly have found the varieties that grew there as interesting as their collector and caretaker. It is in the garden at "Manono" with its olive tree that we may imagine the gulf separating the exile and the established immigrant, momentarily at least, overcome and picture Wolfskehl in Dunedin "erst jetzt heimisch in New Zealand."

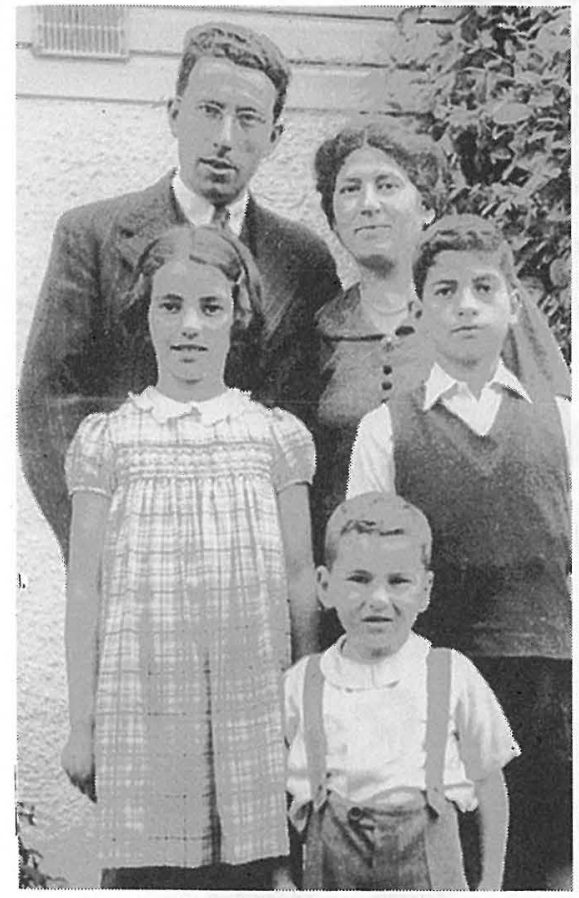

Steinhofs, Dunedin 1943

[Photo: Hanna Urmann (Steinhof)]

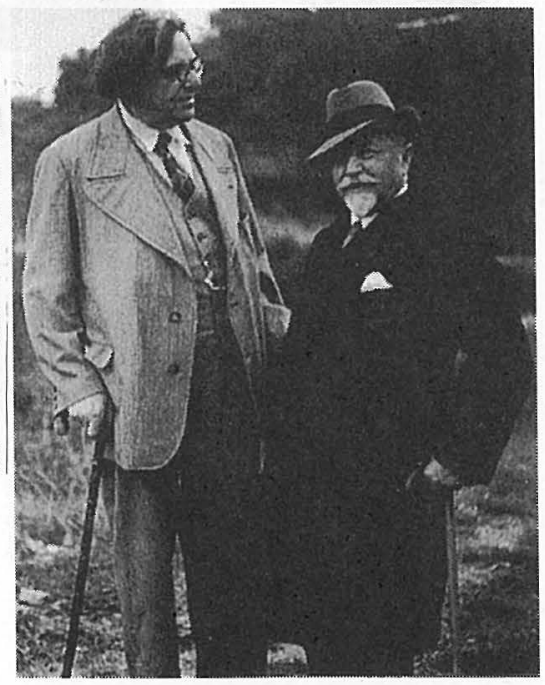

Karl Wolfskehl with Willi Fels, Dunedin [Photo: Hanna Urmann (Steinhof)]

95 H.D. Skinner, Willi Fels, C.M.G., p. 13. 


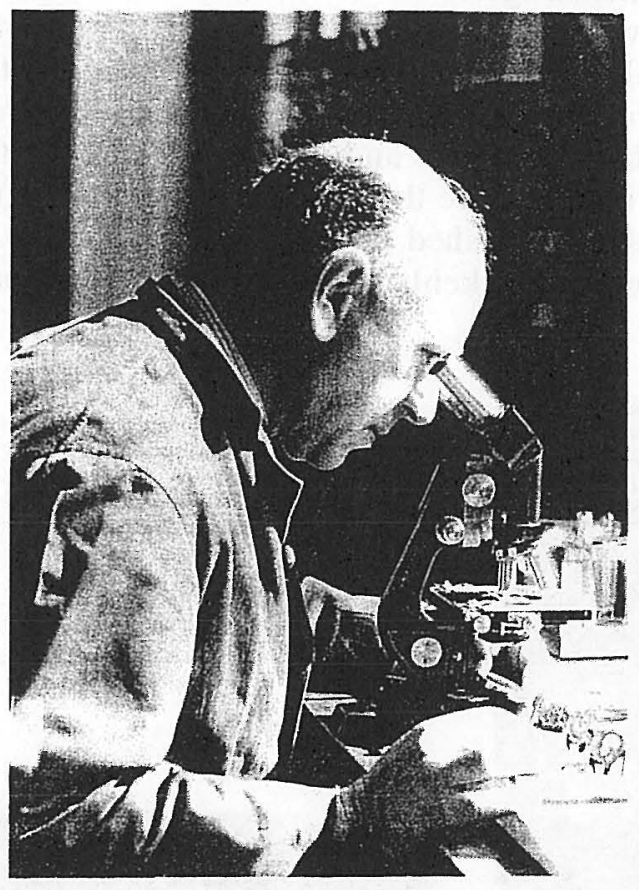

Walter Edwin Griesbach, Dunedin, about 1960 (Photo: Prof. John Borrie)

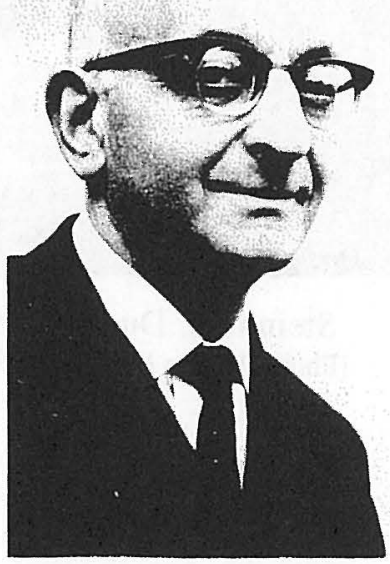

Dr Felix Grayeff

(Photo from: Felix Grayeff, Migrant Scholar. An Autobiography) 